\title{
The Situation of Colonial 'Other' in V. S. Naipaul's A House for Mr. Biswas
}

\author{
Tahereh Siamardi (Corresponding author) \\ Department of English Literature, Karaj Branch, Islamic Azad University, Karaj, Iran \\ PO Box 31485-313, Karaj, Iran \\ E-mail: Tahereh.Siamardi@gmali.com \\ Reza Deedari \\ Department of English Literature, Karaj Branch, Islamic Azad University, Karaj, Iran \\ PO Box: 31485-313, Karaj, Iran \\ Email: R_deedari@yahoo.com
}

Doi:10.7575/aiac.alls.v.7n.1p.122

URL: http://dx.doi.org/10.7575/aiac.alls.v.7n.1p.122
Received: $15 / 09 / 2015$

Accepted: 11/11/2015

\begin{abstract}
The focus of the present study is to demonstrate traces of Homi k. Bhabha's notion of identity in V.S. Naipaul's A House for Mr. Biswas (1961). As a prominent postcolonial figure, Bhabha has contemplated over the formation of identity in the colonizing circumstances. He discusses on what happens to the colonizer and the colonized while interacting each other, arguing that both the colonizer and the colonized influence one another during which their identity is formed, fragmented and alienated. In considering Naipaul's A House for Mr. Biswas as postcolonial text, by the help of postcolonial theories of Homi Bhabha, it is argued that, mentioned novel sums up Naipaul's approach to how individuals relate to places. This novel shows that individuals' quest for home and a place of belonging is complicated first, by the reality of homelessness, and second, by the socio-cultural complexities peculiar to every place. In other words, the reality of homelessness makes the desire for home, elusive. A House for Mr. Biswas describes the story of homeless and rootless immigrants who lack identity and security in the colonial world. In this novel Naipaul deals with shifting identities, roots, homes and changing realities of migrants.
\end{abstract}

Keywords: Identity, Ambivalence, Other, Creolization, Mimicry, Clash of cultures, Unhomeliness

\section{Introduction}

This paper is the study of V. S. Naipaul's A House for Mr. Biswas through the application of Bhabha's postcolonial notions. Homi K. Bhabha, is one of the famous conemporary voices in postcolonial studies, who was born in 1949 in Bombay, India. He received his bachelor's degree from Elphinstone College, University of Bombay, and his doctorate from Christ Church, Oxford. After teaching at Sussex University (1978-94) and the University of Chicago (1994-2000), Bhabha moved to Harvard University, where he is Ann F.Rothenberg Professor of English and American Literature, and chair of the program in History and Literature (Hale, p. 716, 2006). Bhabha's analysis of colonial experiences is grounded in the work of Frantz Fanon, especially his theories of racial difference and mimicry, Michel Foucault, Jacques Derrida, and Jacques Lacan (Castle, p. 202, 2007). As an important postcolonial theorist, Bhabha argues that in the encounter of the colonizer and the colonized both cultures are affected, and neither culture is pure. In the writings of Bhabha, depicted best in The Location of Culture (1994), he forms a series of concepts that work to 'undermine' and challenge self and other. In the novel, A House for Mr. Biswas, Naipaul depicts the situation of the colonial 'other' to reach some sort of personal identity. The postcolonial precepts such as Identity Formation and Cultural Diversity/ Multiculturalism, are the features that in this study the researcher attempts to trace in V. S. Naipaul's $A$ House for Mr. Biswas through Homi Bhabha's theories.

Naipaul's A House for Mr. Biswas is a tragicomic novel set in Trinidad in 1950s, and was published in 1961.In this book Naipaul deals with shifting identities, roots, homes and changing realities of migrants. "The novel takes its subject matter from the excluded peoples who have been alienated from societies to which they apparently belong, and who are in search of an identity"'(Recep Tas, p. 2, 2011). Timothy Weiss in his book On the margins : the art of exile in V.S. Naipaul, (1992), interprets Naipaul's approach to India as, an "idea" rather than observation of place, saying that for Naipaul "India is not precisely a place, but an idea, a state of mind" (Weiss, p. 18, 1992).

A House for Mr. Biswas (1961) has been Naipaul's acclaimed novel based on his father's life in Trinidad in that Naipaul pays tribute to his father's life. Despite the fact that Naipaul has produced various accounts of his life, his early works are reticent about its detail. He tells stories which show us ourselves and the reality we live in. His use of language is as precise as it is beautiful, fraught with simple, strong words, with which he expresses the humanity of all of us. However, he sketches himself more freely on the subject of his life in interviews than in his non-fiction 
and fiction. His declarations in interviews reveal a tendency to dramatize himself in terms of an "overstated pessimism", but they are broadly consistent with the sense of his life which is attainable from his writings (Hayward, p. 17).

\section{Homi k. Bhabha and Postcolonialism}

Postcolonial theory is concerned with a range of cultural engagements: the impact of imperial language upon colonized societies; the effect of European "master discourse" such as history and philosophy; the nature and consequences of colonial education and the links between western knowledge and colonial power. In particular, it is concerned with the responses of the colonized: "the struggle to control self-representation through the appropriation of dominant languages, discourses and forms of narratives; the struggle over the representations of place, history, race and ethnicity; and the struggle to present a local reality to a global audience." (Tyson, p. 419, 2006)

Homi k. Bhabha, the critic who the researcher used and applied his theories and ideas in this research is one of the influential and important figures of postcolonial studies. The gist of Bhabha's theoretical framework is epitomized in his book Location of Culture in which he discusses the concepts such as Mimicry, Ambivalence, Hybridity, and Identity.... In his works and theories, Bhabha is inspired by a great number of twentieth-century theorists. Even though "the wit and wisdom of Jacques Derrida" is constitutional to his achievement, Bhabha makes use of a wide range of twentiethcentury theorists throughout "The Commitment to Theory." Founding on the significant notion of nations declared by Benedict Anderson in Imagined Communities (1983), Bhabha puts emphasis upon "how nationality is narratively produced, rather than arising from an intrinsic essence." From Mikhail Bakhtin, he borrows "the concept of dialogue to stress that colonialism is not a one-way street but entails an interaction between colonizer and colonized" (Leitch, p. 2377-78, 2001).

In The Location of Culture (1994), a collection of his most important essays, Bhabha forms a series of concepts that work to 'undermine' and challenge self and other. The most famous example of these concepts, Bhabha's theories emphasizes the hybridity of cultures, which on one hand in its simple way refers to 'the mixedness whether mixedness of culture, politic or language, or even "impunity" of cultures_ so long as we don't imagine that any culture is really pure (Huddart, p.6,2006). Bhabha's main focus is on what happens on the borderlines of cultures and also in-between cultures through what he calls luminal, 'meaning that which is on the border or the threshold' and emphasizes on what is in between fixed cultural forms or identities like self and other that is central to the creation of new cultural meaning. In fact, Bhabha's work is studying of how language transforms its actual meaning through its confrontation of colonizer and colonized.

Edward Said believes that the West has made a binary opposition between the West and the East considering the East as the Other. He believes that the "established binary opposition between of the West/ the Other must be abolished along with its racial and religious prejudices" (Bressler,p. 241,2007). Bhabha builds on Said's concept of the Other and Orientalism saying in the interaction between the two sides, no culture can claim to remain fix and uncontaminated. However, the colonial experience proves that the colonizer is affected too as the colonized do. With the help of the theory of Lacan on how the identity gets shaped, Bhabha offers us "analyses in which the identity of the colonizer cannot be very well separated from that of the colonized or at least from the supposed identity of the colonized" (Berten, p. 207, 2001).

According to Lacan, our identity gets constructed based on the interaction we make with others and the Other. The others in Lacan's outlook refer to every individual in our daily life, who hails us as a subject. As Lacan says, "the subject, while he may appear to be the slave of language, is still more the slave of a discourse in the universal movement of which his place is already inscribed at his birth, if only in the form of his proper name" (p.433,1979). Bhabha, like Lacan, believes that our identity is unstable and is constructed in interaction with Other and the others. Both colonizer and the colonized are responsible in defining and shaping their identity. Moreover, Bhabha points out the colonizer's dependency on none-friendly others in the interaction.

Ambivalence is a rife term used in Bhabha's studies in. Ambivalence as a colonial and postcolonial aspect is the most central attention of Bhabha. There is a controversial statement in which Bhabha says that "ambivalence represents the existing fluctuating relationship between mimicry and mockery". (Bhabha, p.87,1994); however it is worth of mentioned that ambivalence is an undesirable aspect of colonial discourse for the colonizer. The relationship between colonizer and colonized which is the complex mix of 'attraction and repulsion' is called ambivalent in Bhabha's viewpoint. Considering colonizer who moves to the host's culture and society, colonial relationship then refers to relationship between these two groups. As Tyson says, " to be unhomed is to feel not at home even in your own home because you are not at home in yourself: your cultural identity crisis has made you a psychological refugee, so to speak" (p. 421, 2006). Bhabha calls this feeling of being caught between two cultures unhomeliness_the concept that is often referred to as double consciousness. This feeling of confusion and abandonment by both the colonizer's and the colonized's cultures often makes the colonized a psychological refugees since their cultures have been blended and they cannot strongly say to which culture they do belong.

One of the most significant concepts in the postcolonial studies is the discourse of stereotypes. Bhabha argues that colonial discourse seeks to produce knowledges of two distinct and antithetical colonial subjects. He starts the essay with an assertion of the importance of 'fixity', a concept whose key discursive strategy is the stereotype, where the Other is fixed as unchangeable, known, and predictable. However, the stereotype is also an ambivalent mode of constructing the Other and it is not a simple assertion of difference but a complex articulation of a contradictory belief. 
While the colonized are fixed as unchanging, the stereotypes they are identified with is often one of disorder, anarchy and licence. Thus, the stereotype is "a complex, ambivalent, contradictory mode of representation, as anxious as it is assertive" (Bhabha, p.70).

Other important key in Bhabha's theory is the term hybridity. As defined by Bhabha, 'hybridity' is the condition of doubleness and it occurs through interaction of two separate identities. For Bhabha "all forms of culture are continually in a process of hybridity" (Bhabha, p.154). In fact the concept of hybridity formulated in the work of Homi Bhabha in the 1980s that is original mixedness of something like mixedness of language and culture of some different people of different races. According to Bhabha, "Hybridity is a new cultural and a privileged third space, the hybrid can be considered as something that is "neither the one nor the other"'( Bhabha, p. 10, 994). Bhabha believes that hybridity is camouflage, in fact camouflage of self-identity and mimic other culture that the immigrant (colonized) creates through polarization between self and other. Also in this research it should be mentioned that Other refers to the colonizer or (as told before) the host, because as someone moves to the other land or society feels a sense of strange identity that doesn't belong to the new place and to the new home, therefore tries to adapt him/herself to new situation by mimicking native people, it sometimes lead them to hybridize their own culture and language with the new situation culture and language and then lost the way and create an identity that belongs to nowhere, this as Bhabha says" is just like a heresy" (p. 226, 2007). He notes "how newness enters the world" (p. 227) and it is depended on a "process of translating and transvaluing cultural differences" (p. 252).

Cultural diversity or multiculturalism, refers to "the social and political movement and/or position that views differences between individuals and groups to be a potential venue of cultural strength and renewal; multiculturalism celebrates and explores different varieties of experience stemming from racial, ethnic, gender, sexual and/or class differences" (Wolfreys, Robbins, Womack, p. 69, 2006).In the essay 'The commitment to theory' (1988), Homi Bhabha describes that the recording signifiers of cultural diversity which is a mere reference to a range of separate and distinct groups of behavior, attitudes and values. It can be understood from such a framework that such differences are 'merely aberrant or exotic', as was 'implicit in imperialistic ethnographies' (qtd in Ashcroft et al, p. 60).

In the context of postcolonial studies, the term "Creolization" is conceived as "the process of intermixing and cultural change that produces a creole society," especially in the Caribbean. While the creolization processes might be argued to be going on throughout the world, the term has usually been applied to 'New World' societies ( particulary the Caribbean and South America) and more loosely to those postcolonial societies whose present ethnically or racially mixed populations are product of European colonization (Ashcrofts, p. 58). The leading theorist of creolization, Edouard Glissant, stresses even more explicity creolization's opposition to essence: what it teaches us is above all that "Creolization is unpredictable, it cannot solidify, become static, be fixed in essences or absolutes of identity." Thus, identities and differences are always in process (Britton, p.16, 1999). Homi Bhabha also describes creolization as a dynamic process, which prevents the emergence of absolute identities. The proliferating, unstable nature of creolization therefore makes the process of identity-formation into what Homi Bhabha has called "the articulation of antagonistic or contradictory elements" (Gallagher, p. 260, 2003).

The other term, which Bhabha has talked about, is Mimicry. According to Bill Ashcroft et al in their Key Concepts in Post-Colonial Studies (1998), 'mimicry' is "an increasingly important term in post-colonial theory, because it has come to describe the ambivalent relationship between colonizer and colonized. When colonial discourse encourages the colonized subject to 'mimic' the colonizer, by adopting the colonizer's 'cultural habits, assumptions, institutions and values, the result is never a simply reproduction of those traits. Rather, the result is a 'blurred copy' of the colonizer that can be quite threatening" (p.139). Ashcroft et al continues to claim that this kind of mimicry is not very far from mockery, because mimicry seems "to parody whatever it mimics." Therefore, "mimicry locates a crack in the certainty of colonial dominance, an uncertainty in its control of the behavior of the colonized" (139). As Ashcroft argues, mimicry is inseparable from Bhabha's idea of the ambivalence in the discourse of colonialism. For Bhabha in the process of mimicry "the colonized subject is reproduced as "almost behavior, manners and values by the colonized contains both mockery and a certain "menace", so that mimicry is at once resemblance and menace" (p.80).

All the terms which have been explained through the eye of Bhabha, are to emphasize the fact that in the process of interaction between the colonizer and the colonized, the identity of both groups undergoes a serious changes. As it was mentioned as a prominent postcolonial figure, Bhabba has contemplated over the formation of identity in the colonizing circumstances. He discusses on what happens to the colonizer and the colonized while interacting each other, arguing that both the colonizer and the colonized influence one another during which their identity is formed, fragmented and alienated. This study argues how people who have been colonized once, particularly the colonial migrant intellectuals who had left the colonies to locate themselves in the centers of the world, imitate their colonial masters and struggle to internalize the values and cultures of the West.

\section{The Situation of a Colonial 'Other'}

\subsection{Mr. Biswas as an Other in a Colonized Society}

A House for Mr Biswas is a narrative of a male protagonist located in the period of British colonialism. The impact of colonisation is everywhere in the novel. Much of Naipaul's novel is given to depicting the groups of Indian people in Trinidad. Biswas tells the story of its protagonist, Mr. Biswas from birth to death, each section dealing with different phases of Mr. Biswas's life. Mr. Biswas is caught between the old culture of India and English people which are shown in many ways. 
Ashcroft et al in their Key Concepts in Post-Colonial Studies assert that: "the 'other' is anyone who is separate from one's self. The existence of others is vital in defining what is 'normal' and in locating one's own place in the world" (p.169, 2000). In the novel A House for Mr. Biswas Naipaul depicts the situation of the colonial 'other' to reach some sort of personal identity. Although the characters themselves are related in the usual sense of the word, they are noticeably separate from one another, and work against each other in the quest of their own satisfaction.

In the traditional society of Trindad Mr. Biswas is considered as an Other. His birth is considered ominous as he is born with extra finger and a Hindu pundit predicts that it will bring bad luck.

"What is it?" the old man asked. "Boy or girl?"

"Boy, boy," the midwife cried. "But what sort of boy?

Six-fingered, and born in the wrong way."

The old man groaned and Bissoondaye said, "I knew it. There is no luck for me."

(A House for Mr. Biswas. P.5, 1995)

The prophecy seems to be correct when as a child, Mr. Biswas is indirectly and unintentionally responsible for the death of his father, and his family is sooner or later broken apart as a result.

"That boy!" Dhari said. "He has murdered my calf and now he has eaten up his own father."

Lakhan brought up Raghu unconscious. They rolled him on the damp grass and pumped water out of his mouth and through his nostrils. But it was too late. (p. 13)

Later in the story, as the youngest child of family, he stays with his mother, but she lacks the ability to support him and influence his education. He basically becomes a child of circumstance, and his life becomes accidental. In his job in Tulsi store, he is fascinated to a young girl's smile and it motivates him to write her a note which her family interprets as a love letter, and he unexpectedly finds himself engaged, with no way of detaching himself from the situation.

After marriage Mr. Biswas and his wife Shama live in Hanuman House with Shama's parents and her relatives. Very soon he finds himself in conflict with one member of the family or another. Then he is sent from the house to run a store on one of the Tulsi properties. When Mr. Biswas experiences financial difficulties Seth, Mrs. Tulsi's brother-in-law offers him a position as a driver on one of the Tulsi sugar estates, and he accepts, under Shama's persuading.

After that Mr. Biswas spends his whole life fearing the 'void', and moves from one house to the other and tries to occupy a space of his own. Mr. Biswas is impatient to build a house, but he does not have very much money. The image of dispossession and rootless ness, and being homeless, becomes the repeated metaphor in A House for Mr. Biswas. Mr. Biswas as an Other in a colonized society is a man who is historically displaced and struggling in a ruined land. The house in fact becomes a substitute for the unconscious search for a lost land. Mr. Biswas unconsciously in the entire course of the novel seeks to substitute this search with the search for a house of his own.

\subsection{Search for Identity}

A House for Mr. Biswas describes the story of a homeless and rootless immigrant who lacks identity and security in the colonial world. The process of colonization brings forth new patterns of cultural behavior and value system in creole society of Trindad. In this book Naipaul deals with shifting identities, roots, homes and changing realities of migrants. Naipaul has written extensively about different aspects of post-colonial society, viewed from post-colonial perspective.

The Tulsi household is a metaphor for the British Empire in Trinidad and Tobago, headed by a Queen, Mrs. A House for $\mathrm{Mr}$ Biswas, metaphorically, is a miniature world which symbolizes the colonial world. Mr. Biswas's personal conflict with the stronghold of the Tulsi household is a search for freedom and the struggle for personality. As Singh underlines; "Mr. Biswas is the unaccommodated man representing the outcast's symbolic quest for a place in the hostile universe" (p.126, 2011). The Tulsis are symbol of the world of colonialism and during the course of the story Mr. Biswas is repeatedly accused of not being grateful to the Tulsis.

"I am giving you notice," Mr. Biswas shouted. "I curse the day I step into your house."

"Man, man."

"You curse the day," Mrs. Tulsi said. "Coming to us with no more clothes than you could hang on a nail."

This wounded Mr. Biswas. He could not reply at once. "I am giving you notice," he repeated at last. "I am giving you notice," Mrs. Tulsi said.

"I gave it to you first."(A House for Mr. Biswas. P.226, 1995)

At surface it seems that Tulsi family provides shelter and job for Mr Biswas but in fact Mr Biswas is like a slave in Tulsis's household and they use him as a worker to improve their economy. Naipaul's Biswas is fighting for freedom and recognition and for him to build a house of his own means freedom and recognition. Mr. Biswas is in search of a home by which he will be able to find his identity. As Kumar Parag underlines "a house is not just a matter getting a 
shelter from heat, cold or rain. In fact, it is both an imposition of order and a carving-out of authentic selfhood within the heterogeneous and fragmented society of Trinidad" (p.139. 2008).

\subsection{Co-existence of Different Cultures}

In the story of Naipaul's A House for Mr Biswas the co-existence of different cultures is reflected in the novel from various points of view and Cultural difference is the main subject of this story. Cultural difference or multiculturalism refers to a variety of beliefs, custom and behaviors. It establishes a kind of Creole society in which various cultures, languages, beliefs and religions are interacting with one another. As Ashcroft says such a society is made in a process in which various cultures clash in one specified land thus this "is process of intermixing and cultural change that produces a creole society" (p.51, 2000). Trindad as an example here, setting of the novel A House for Mr Biswas, is full of people with different cultures and languages. Naipaul based A House for Mr. Biswas on his own experiences in Trinidad.

In the creole society of Trindad cultures are heterogeneous and Trinidad's diversity has affected its culture. English is the official language, but four creole languages (mixtures of English, Spanish, French, and African tongues) are also spoken. About 40 percent of Trinidadians are of African descent; another 40 percent are of Indian descent; and the rest, referred to as Creoles, and are mixtures from different ethnic backgrounds. In A House for Mr Biswas, the characters speak Hindi, the official language of India, as well as Trinidadian English, which is characterized by a simplified grammar and the omission of words or word endings.

In this novel we have an example of how different people cope with different cultures and how they try to adopt to creole society. During the course of story we see some characters like Biswas who try to adopt new culture and on the other hand characters like Tulsis who seek to perverse their culture.

Tuttle and Mr. Biswas had something in common: they both felt that by marrying into the Tulsis they had fallen among barbarians. W. C. Tuttle regarded himself as one of the last defenders of brahmin culture in Trinidad; at the same time he considered he had yielded gracefully to the finer products of Western civilization: its literature, its music, its art. He behaved at all times with a suitable dignity. He exchanged angry words with no one, contenting himself with silent contempt, a quivering of his longhaired nostrils.

(A House for Mr. Biswas. P.219, 1995)

By the end of the story we see the changes which took place in the history and culture of Indian people. The shift from Hindi to English. This story is not only a story of a man but also the history of culture. A House for Mr depicts a multicultural society in which people try to adopt themselves to the new environment by mimicking their language and culture that result in creating a cross-cultural society.

\subsection{The Impact of Colonisation}

The impact of colonisation is everywhere in the novel. The family structures and social customs of the Indians in Trinidad is related to political situation. The people among which Mr Biswas is born are trapped in miserable situations and are considered as inferior in the discourse of colonizers.

Naipaul in his book Jasmine says that "Trinidad was an island without a "mythology"; therefore, to them, Trinidadians, all literatures were foreign, since during the colonization period Trinidad lacked a literary tradition and all books came from abroad" (46-47). As the narrator of the A House for Mr Biswas discusses in the missionary schools of Trindad students learn to recite Christian prayers in Hindi with noticeable purpose of conversion. The education Biswas received was part of the empire's civilizing mission and cultural values of Biswas's Hindu background were disregarded. In this story Biswas presents an independent Caribbean, but one that is crippled by colonial education and cultural colonization.

It was by means of his colonial education that Mr Biswas became familiar with the dominant values and culture of canonical literary works and he used literature as a way of escape from bitterness of real world.

He stayed in the back trace and read Samuel Smiles. He had bought one of his books in the belief that it was a novel, and had become an addict. Samuel Smiles was as romantic and satisfying as any novelist, and Mr. Biswas saw himself in many Samuel Smiles heroes: he was young, he was poor, and he fancied he was struggling. But there always came a point when resemblance ceased. The heroes had rigid ambitions and lived in countries where ambitions could be pursued and had a meaning. He had no ambition, and in this hot land, apart from opening a shop or buying a motorbus, what could he do? What could he invent? (A House for Mr. Biswas. P.189, 1995).

As a result of colonization, reality for the colonized people like Biswas is fragmented and he is continually in the process of searching for a sense of his own self. But according to Cooke "arriving is a process which cannot come to an end" (p.140,1980). Biswas as a colonial subject has gone through the colonial education system and internalized the values which are established by colonizers. As it is depicted in the novel, although for people like Biswas education is a source of hope for escaping from poverty but this escape is attained by rejecting their own culture and traditions.

Naipaul's sense of detachment can best be understood in the context of the conditions, in which he grew up, as a member of a culturally displaced minority community, and in relation to the nature of colonial education, which 
encouraged an identification with the values of English civilization, and increased his sense of distance from the culture that surround him. His subsequent novels, therefore, developed more political themes and he began to write about colonial and post-colonial societies in the process of decolonization.

In this novel Naipaul depicts the defenselessness of the Indian family structure in a colonial setting. The break of the Indian families is due to social, economic and political reasons; they seem not to have any political rights and their claim to the place where they live is so questionable and they can be easily removed from their house.

And so Mr Biswas came to leave the only house to which he had some right. For the next thirty-five years he was to be a wanderer with no place he could call his own, with no family except that which he was to attempt to create out of the engulfing world of the Tulsis. For with his mother's parents dead, his father dead, his brothers on the estate at Felicity, Dehuti as a servant in Tara's house, and himself rapidly growing away from Bipti who, broken, became increasingly useless and impenetrable, it seemed to him that he was really quite alone (A House for Mr. Biswas. P.40, 1995).

Because of the limitations that socially imposed on him due to his colonial background, Biswas's freedom is limited and he is always at a standstill. Mr. Biswas is from a race not located in its own country. A race that has been uprooted, alienated and dislocated from its origins. And since every ethnic group has its ethic, cultural and historical specifications, its dislocation is distressing and complicated because its members cannot find a home of their own.

\subsection{Experiences of Displacement}

According to Bill Ashcroft et al in their Key Concepts in Post-Colonial Studies, the term ambivalence "first developed in psychoanalysis to describe a continual fluctuation between wanting one thing and wanting its opposite. It also refers to a simultaneous attraction toward and repulsion from an object, person or action" (p.12). Homi Bhabha adapted this term into colonial discourse theory and believed that the term 'ambivalence' describes the complex mix of attraction and repulsion that characterizes the relationship between the colonizer and the colonized. In this novel the same concept can be noticed as well fitting Bhabha's conception of the ambivalence.

During the course of the novel as it is shown Biswas leaves the rural society of Trinidad to go to Port of Spain. Here rural norms and taboos have no value and Mr Biswas encounters diverse lifestyles. He starts to notice "change followed change”. (A House for Mr. Biswas. P.367, 1995)

Port of Spain opens new avenues for Mr. Biswas. The city provides him the opportunities he has searched for. He feels that he is not a nonentity anymore. He forgets his wish to have a space of his own and enjoys his success and family life. Mr. Biswas manages to get a loan from Ajodha and buys a house in Port of Spain. He describes his house thus:

The sun came through the open window on the ground floor and struck the kitchen wall. Wood work and frosted glass were hot to the touch. The inside brick wall was warm. The Sun went through the home and laid dazzling strips on the exposed staircase" (p. 572).

These words visibly reveal Mr. Biswas's happiness and sense of fulfillment and his battle against the forces of oppression. His happiness, however, is short-lived and taken by Tulsis as absolute authorities. In this book the aim of Naipaul is not only to depict the Hindu background but also to relate it to the circumstances in which he is living. Here Mr. Biswas is depicted as an individual who is portrayed as an unlucky man who experiences hostility and humiliation from society.

In the Port of Spain Mr. Biswas faces different circumstances as a result of experiencing new culture in the dominant colonial situation. Thus he finds himself caught between two feelings, that of liking or disliking new condition. He is in some way attracted toward it and on the other hand he hates it. This feeling is called ambivalence which the colonized experience in the colonizer's atmosphere. Here in the story Naipaul describes characters complex mix of attraction and repulsion:

Their ritual was debased; the moment they got to England they ate meat and drank to prove their modernity (a Brahmin boy had offered Owad curried com beef for lunch); and, incomprehensibly, they looked down on colonial Indians. The sisters said they had never really been fooled by Indians from India; they spoke of the behavior of the missionaries, merchants, doctors and politicians they had known; and they grew grave as they realized their responsibilities as the last representatives of Hindu culture. (A House for Mr. Biswas. P.257, 1995)

Biswas' manners shows that while he incorporates capitalist values of individuality, he rejects his roots in order to adopt new culture. In this scene we see that he is trapped between what he regarded as utopia and what he is really in which might be called dystopia as he feels ambivalent now toward the situation. During the course of novel we can see that similar to Mr Biswas other characters' minds are obsessed with the idea of utopia. In one part of the story sisters describe the land as below:

The land itself was a wonder. The saman trees had lianas so strong and supple that one coulswing on them. All day the immortelle trees dropped their red and yellow bird-shaped flowers through which one could whistle like a bird. Cocoa trees grew in the shade of the immortelles, coffee in the shade of the cocoa, and the hills 
were covered with tonka bean. Fruit trees, mango, orange, avocado pear, were so plentiful as to seem wild. . . The sisters spoke of the hills, the sweet springs and hidden waterfalls with all the excitement of people who had known only the hot, open plain, the flat acres of sugarcane and the muddy ricelands. Even if one didn't have a way with land, as they did, even if one did nothing, life could be rich at Shorthills. (A House for Mr. Biswas. P.354, 1995)

All the characters of the story are wishing for a better world and hope. They consider the land as a tropical paradise where the ideals of communal living may be established. More than any other character in the story Mr Biswas's mind is obsessed with the idea of fantastic landscape, but at his first visit he gets surprised.

\subsection{Search for Independence}

Naipaul's emotional bond with Indian which remains for him an area of pain and ache, is projected in the novel $A$ House for Mr Biswas. According to Freed the fragmented society of Trindad "demonstrates a disorder which originates from within" (p.69, 2004). A House for Mr. Biswas deals with the historical period of colonialism and the experiences of migration and displacement with respect to Trinidad. According to Parag "A House for Mr. Biswas delineates the traumas of a tainted and troubled past and the attempts to find a purpose in life, beautifully analyzing the sense of alienation and the pangs of exile experienced by the characters" (p.135, 2008). A House for Mr. Biswas is the story of search for independence and identity of a Brahmin Indian living in Trinidad. As Gourevitch believes. The story induces a man's quest for autonomy "against the backdrop of postcolonial Trinidad" (p. 27, 1994)

On the surface the novel might be about Mr. Biswas as an individual, but in fact he is the representative of people who suffered many problems in the shift from the organic concept of the family towards the modern notion of the individual on the social level. Mr. Biswas as a postcolonial subject all his life struggles to leave a mark on the human history and for him house is the symbol of shelter, security and achievement. The meaning of A House for Mr. Biswas is clear in the Prologue:

How terrible it would have been, at this time, to be without it; to have died among the Tulsis; amid of the squalor of that large, disintegrating and indifferent family; to have left Shama and the children among them, in one room; worse, to have lived without even attempting to lay claim to one's portion of the earth; to have lived and died as one had been born, unnecessary and unaccommodated. (A House for Mr. Biswas. P.14, 1995)

The search for a house is supposed to offer some renovation of freedom and a source of belonging. The theme of $A$ House for Mr. Biswas is drawn from the social, racial and political environment of the West Indies in a state of transition from colonial to dominion status and the hero of the story is engaged in a serious battle against the forces of oppression.

\section{Conclusion}

A House for Mr Biswas is a narrative of a male protagonist located in the period of British colonialism. The impact of colonisation is everywhere in the novel. Biswas tells the story of its protagonist, Mr. Biswas from birth to death, each section dealing with different phases of Mr. Biswas's life. Mr. Biswas is caught between the old culture of India and English people which are shown in many ways. A House for Mr. Biswas describes the story of a homeless and rootless immigrant who lacks identity and security in the colonial world. The process of colonization brings forth new patterns of cultural behavior and value system in creole society of Trindad. In this book Naipaul deals with shifting identities, roots, homes and changing realities of migrants. Naipaul has written extensively about different aspects of post-colonial society, viewed from post-colonial perspective.Biswas, as the protagonist of the story, is searching for a house of his own throughout his life. He represents displaced people having no identity in Trinidad since they are unhomed from their own land and in this new environment, they feel unstable. As a result of being unhomed and having no identity they have to create a new identity of their own. The first step is to imitate the colonizer's way of behavior and absorb its norms through which the characters in this novel gradually lose their language, culture, custom and their belief in Hindi religion and their religion becomes a mixture of Christian and Hindi. Moreover, they become confused as to which culture they should stick to and thereby find an ambivalent personality.

In the novel A House for Mr. Biswas Naipaul depicts the situation of the colonial 'other' to reach some sort of personal identity. Although the characters themselves are related in the usual sense of the word, they are noticeably separate from one another, and work against each other in the quest of their own satisfaction.

On the surface the novel might be about Mr. Biswas as an individual, but in fact he is the representative of people who suffered many problems in the shift from the organic concept of the family towards the modern notion of the individual on the social level. Mr. Biswas as a postcolonial subject all his life struggles to leave a mark on the human history and for him house is the symbol of shelter, security and achievement. In this novel Naipaul depicts the defenselessness of the Indian family structure in a colonial setting. The break of the Indian families is due to social, economic and political reasons; they seem not to have any political rights and their claim to the place where they live is so questionable and they can be easily removed from their house. 


\section{References}

Ashcroft, B., Gareth, G., and Helen T. (2000). Post-colonial Studies: The Key Concepts. London: Routledge.

Bertens, Hans. (2001). Literary theory. New York: Routledge.

Bhabha, H. K. (990). "DissemiNation: Time, Narrative, and the Margins of the Modern Nation." Nation and Narration. London: Routledge.

---. (994). "Of mimicry and, man: The ambivalence of colonial discourse". Location of Culture. London: Routledge, p. $85-92$.

---. (1994).The Location of Culture. London: Routledge.

Bressler, C. (2007). Literary Criticism. New Jersey: Pearson Prentice Hall.

Britton,Celia.(1999). "Edouard Glissant and postcolonial Theory: Strategies of Language and Ressistance". The University Press of Virginia.

Castle, Gregory. (2007). Blackwell Guide to Literary Theory. Oxford: Blackwell.

Cooke, John. (1980).“A Vision of the Land: V.S. Naipaul’s Later Novels.” Jounals of Caribbean Studies.

Freed, Lynn. (2004).“The Critical Is Personal.” The New York Times Book Review.

Gallagher, Mary. (2003). Ici-Lá: Place and Displacement in Caribbean Writing in French. Rodopi B.V., AmesterdamNew York, NY.

Gourevitch, Philip.(1994). Naipaul World. Commentary, London: Penguin.

Hale, Dorothy J.(2006). The Novel: An Anthology of Criticism and Theory 1900-2000: Blackwell publishing Ltd.

Heyward, Helen. (2002). The Enigma of V. S. Naipaul: Sources and Contexts. New York: Palgrave Macmillan.

Huddart, David. (2006). Homi K. Bhabha, Routledge Critical Thinkers. New York: Routledge.

Jonathan Hart. (1994). Traces, resistance and contradictions: Canadian and international views on postcolonial theory, the knowledge web.

Lacan, J. (1979). The Language of the Self: The Function of Language in Psychoanalysis.New York: Johns Hopkins University Press.

Leitch, Vincent B. (2001), General Editor. The Norton Anthology of Theory and Criticism. $1^{\text {st }}$ ed. New York: W. W. Norton \& Company.

Moore-Gilbert, B. (1997). Postcolonial Theory: Context, Practices, Politics. London: Routledge .

Naipaul, V.S. (961). A House for Mr. Biswas. London: David Campbell Publishers.

Parag, Kumar.(2008). “Identity Crisis in V.S. Naipaul's A House for Mr. Biswas". In: Neither East Nor West: Postcolonial Essays on Literature, Culture and Religion / [ed] Kerstin W. Shands, Huddinge: Södertörns högskola, 135142.

Pitt, R. (2001). York Notes: V.S. Naipaul's A House for Mr. Biswas. London: Longman.

Recep Tas, M. (2011)."Alienation, Naipaul and Mr. Biswas". International Journal of Humanities and Social Science. (Vol. 1 No. 11. p. 115-119).

Singh, Balkar. "Naipaul's Mystic Masseur: A Quest for Identity amidst Deracination”. Ajrsh: Asian Journal of Research in Social Science and Humanities, 1(3), 1-9

Tyson, L. (2006). Critical Theory Today, A User- Friendly Guide. 2th Ed. New York: Routledge.

Weiss, T. (1992). On the margins: the art of exile in V.S. Naipaul, Amherst, University of Massachusetts Press.

Wolfreys, Julian, Ruth Robbins and Kenneth Woma. (2006). Key Concepts in Literary Theory. Second Edition. Edinburg: Edinburgh University Press.

Young, Robert. (2001). Postcolonialism: An Historical Introduction, Oxford: Blackwell Publishers Inc. 